\title{
Perancangan Penampil Grafik Sinyal Ketegangan Otot Perut Dengan Menggunakan Sensor Elektromiografi
}

\author{
1 Hans Yandi Gunawan *), ${ }^{1}$ Florentinus Budi Setiawan \\ ${ }^{1}$ Program Studi Teknik Elektro, Fakultas Teknik, Universitas Katolik Soegijapranata \\ Semarang, Indonesia
}

hansyandigunawan@yahoo.com*)

\begin{abstract}
Abstrak
Kemajuan teknologi dalam bidang kesehatan dapat dimanfaatkan untuk menentukan IMT (Indeks Massa Tubuh) seseorang berada dibawah, sesuai standard maupun diatas standard (18,55 - 22,9).[4] Dengan memanfaatkan sensor pembaca otot atau EMG (Elektromiograph) yang akan mendeteksi tegangan yang dihasilkan otot pada perut, maka akan didapat data berupa angka. Data yang didapat akan digunakan sebagai perbandingan untuk menentukan IMT seseorang. Semakin banyak lemak yang tertimbun pada lapisan kulit maka hasil pembacaan dari sensor EMG ini pun akan menjadi tidak maksimal, berbeda dengan orang yang memiliki kadar lemak yang sedikit. Maka dari itu penelitian ini akan memanfaatkan sensor otot EMG dan kadar lemak pada perut sebagai pembanding untuk menentukan IMT seseorang. Alat yang saya buat ini terdiri dari elektroda yang difungsikan sebagai penangkap sinyal, sensor otot yang akan menguatkan sinyal dan memperhalus sinyal, ATmega8535 yang akan mengolah sinyal masukan dari sensor otot, lalu ada juga LCD yang akan digunakan sebagai keluaran dari ATmega 8535.
\end{abstract}

Kata Kunci : Sensor otot EMG (Elektromiograph), IMT (Indeks Massa Tubuh), AD8226, ATmega 8535.

\section{Pendahuluan}

Akibat dari kemajuan jaman yang membuat segala sesuatu menjadi praktis, banyak orang menjadi malas untuk melakukan segala sesuatu dengan menggunakan tenaga mereka sendiri. Hal ini tentunya akan menyebabkan mereka tidak memperhatikan bentuk tubuh dan berat badan mereka. Tubuh yang jarang melakukan aktifitas akan cenderung menyimpan banyak lemak. Dimana tubuh yang menyimpan banyak lemak cenderung mudah terserang oleh berbagai penyakit.

IMT atau Indeks Massa Tubuh adalah suatu nilai yang digunakan untuk mengidentifikasi massa tubuh seseorang. IMT akan dibagi menjadi 4 kategori yaitu berat badan kurang, normal, berlebih dan obesitas. Cara menghitung IMT yaitu dengan menggunakan rumus :

$$
\text { IMT }=\frac{\text { Berat Badan }(\mathrm{kg})}{\text { Ting } i \tilde{i} \operatorname{Badan}(\mathrm{m})^{2}}[1]
$$

Berdasarkan hasil dari perhitungan rumus tersebut, berikut kategori berat badan yang didapat:

- $\quad$ Dibawah 18,5 = kurang

- $18,5-22,9=$ normal

- $23-29,9$ = berlebih

- $\quad>30=$ obesitas [2]

Pada penelitian ini penulis akan menggunakan sensor otot EMG (Elektromiograph) untuk pengambilan data. EMG (Elektromiograph) adalah suatu sensor otot yang dapat merekam kegiatan suatu otot berupa beda potensial listrik saat otot rileks dan berkontraksi. Sensor otot tersebut akan digunakan untuk membaca sinyal otot pada perut pada beberapa orang dengan berat badan yang berbeda. Setelah data terkumpul, akan dilakukan pembandingan untuk menentukan masuk dalam kategori apa berat badannya. [6][8][9]

Dalam makalah ini akan dibahas tentang bagaimana prinsip kerja sensor otot EMG (Elektromiograph), perancangan alat dan data hasil uji alat.

\section{Studi Pustaka}

Dasar dari penelitian ini adalah memanfaatkan terdapatnya beda potensial listrik saat otot bekerja. Beda potensial listrik tersebut dapat direkam melalui alat yang bernama sensor otot EMG dibantu dengan elektroda sebagai penangkap sinyal tegangan tersebut. Proses yang menyebabkan otot dapat berkontraksi yaitu adanya perpindahan ion Natrium $\left(\mathrm{Na}^{+}\right)$dan Kalium $\left(\mathrm{K}^{+}\right)$. Saat otot berkontraksi, terdapat 3 tahap yaitu Polarisasi (Otot berkontraksi), Depolarisasi (Otot rileks) dan tahap otot berisitirahat. Beda potensial saat otot berkontraksi disebut MUAP (Motor Unit Action Potential). [7][8][9] Berdasarkan teori yang didapat tersebut maka berikut adalah diagram alur tahap kerja alat : 


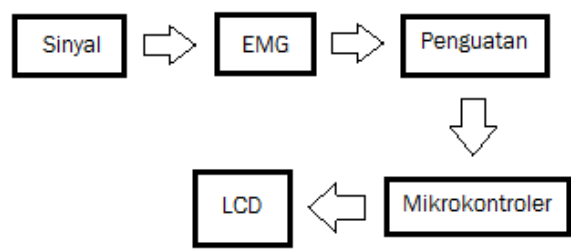

Gambar 1. Diagram Alur Tahap Kerja Alat

\subsection{EMG (Elektromiografi)}

EMG atau Elektromiografi adalah sebuah teknik yang digunakan untuk membaca aktivitas listrik pada otot. Sinyal yang ditangkap oleh sensor ini bukanlah sinyal yang dihasilkan oleh kekuatan otot melainkan sinyal listrik yang dikirim melalui sistem saraf menuju ke serat-serat otot yang akan membuat otot dapat berkontraksi. Sedangkan Elektromiogram adalah hasil sinyal listrik yang tertangkap oleh elektroda. Elektroda yang terpasang pada lapisan kulit ataupun dipasang pada otot berfungsi sebagai penguat atau penangkap sinyal tegangan. Sehingga dengan menggunakan sensor EMG ini kita dapat mengetahui berbagai hal mengenai otot tubuh manusia. Tetapi hasil sinyal tegangan yang dihasilkan oleh otot sangatlah kecil sehingga dibutuhkan sebuah komponen yang berfungsi sebagai penguat. Komponen yang digunakan sebagai penguat pada penelitian kali ini yaitu modul sensor sinyal otot EMG V3. Didalam modul ini terdiri dari penguat, filter, penyearah, EMG envelope dan envelope detector. Modul ini mampu menguatkan sinyal sampai 1000 kali. Envelope detector akan mengeluarkan hasil output berupa titik-titik puncak dari hasil penguatan sebelumnya menggunakan input yang mempunyai amplituda berfrekuensi tinggi. [6][7][8][9][10]

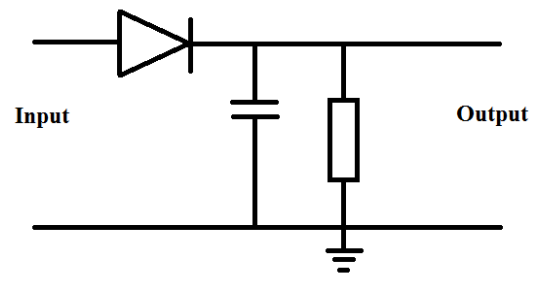

Gambar 2. Envelope Detector

Dengan menggunakan sensor otot ini maka kita dapat menggunakan mikrokontroler secara langsung karena alat ini memang didesain sedemikian rupa sehingga dapat memudahkan penggunaannya. Sinyal yang dihasilkan pun sudah diperkuat, diperbaiki dan dihaluskan sehingga dapat bekerja dengan baik dengan konverter ADC (Analog-to-Digital Converter).

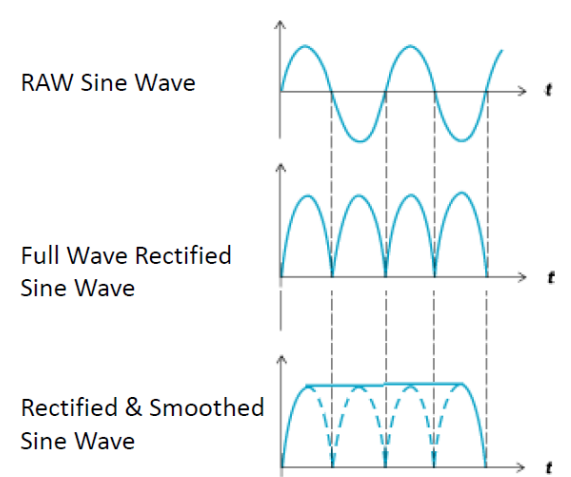

Gambar 3. Sinyal Output Modul Sensor Otot V3 [3]

\section{Perancangan Alat}

Pada penelitian kali ini akan menggunakan konverter ADC (Analog-to-Digital Converter) yang akan mengubah data analog yang didapat dari modul sensor otot EMG V3 menjadi data digital yang akan dimasukkan ke ATmega8535.

\section{a. Modul Sensor Otot EMG V3}

Modul sensor otot EMG V3 ini bertugas sebagai komponen analog dimana didalamnya terdapat komponen sebagai penguat yaitu AD8226 yang mampu menguatkan sampai 1000 kali, dan filter TL084. Selain 2 komponen tersebut terdapat juga evelope detector yang berfungsi sebagai rangkaian demodulasi sehingga sinyal outputnya lebih baik saat bekerja pada ADC mikrokontroler.

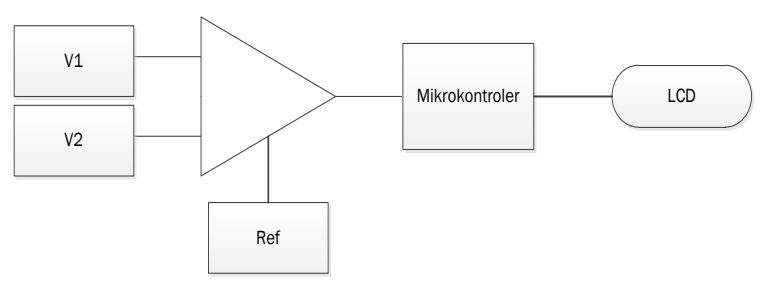

Gambar 4. Alur Pengolahan Sinyal

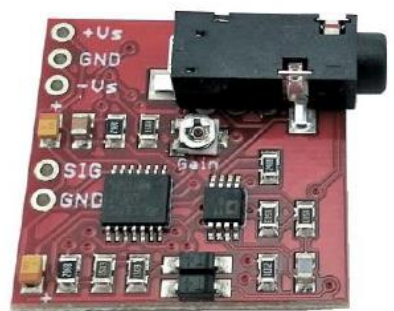

Gambar 5. Modul Sensor Otot V3 [3] 
Untuk mengatur penguatan pada output sinyal otot maka dapat digunakan rumus sebagai berikut :

$$
\mathrm{R}_{\mathrm{G}}=\frac{49,4 \mathrm{k} \Omega}{G-1}[4]
$$

\section{b. ATmega8535}

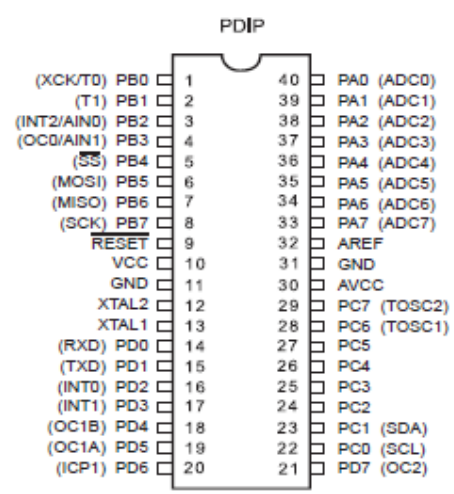

Gambar 6. Pinout ATmega8535 [5]

Mikrokontroler ATmega8535 merupakan mikrokontroler 8 bit berdaya rendah yang mampu mencapai kecepatan maksimal hingga $16 \mathrm{MHz}$. Untuk menjalankan mikrokontroler ATmega 8535 akan diperlukan suatu sistem minimum yang berfungsi sebagai penghubung pinout ATmega8535 dengan Input dan Output data. [5]

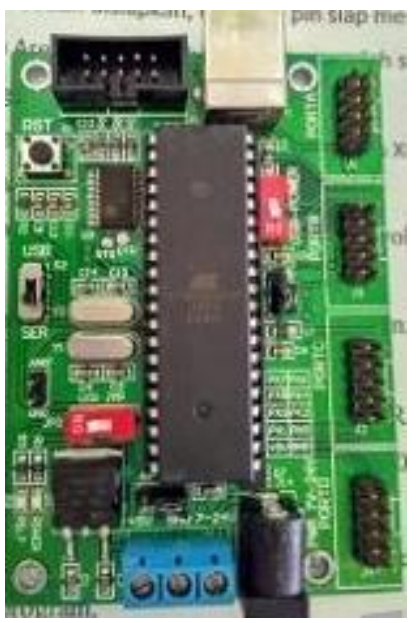

Gambar 7. Sistem Minimum ATmega8535

\section{c. Elektroda}

Untuk menangkap sinyal tegangan yang dihasilkan oleh otot maka diperlukan elektroda sebagai antenna. Teknik pemasangan elektroda yang digunakan pada penelitian kali ini adalah teknik pemasangan intramuscular EMG. Cara ini dipilih karena lebih praktis dan mudah karena cukup menggunakan elektroda tipe gel yang dipasang pada lapisan kulit yang akan dideteksi sinyal tegangan ototnya. Sinyal tegangan yang ditangkap oleh elektroda nantinya akan diteruskan ke modul sensor otot dan data akan diolah oleh mikrokontroler. [7]

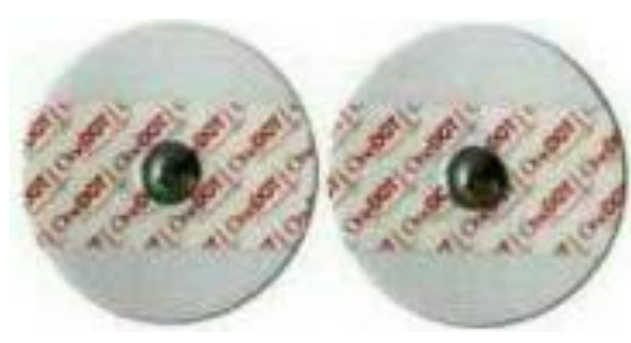
Gambar 8. Elektroda Perak Klorida dengan
Lapisan Gel

\section{d. LCD (Liquid Crystal Display)}

LCD atau Liquid Crystal Display merupakan komponen yang berfungsi untuk menampilkan gambar dengan memanfaatkan sifat modulasi cahaya dari liquid crystal. Liquid crystal adalah sebuah lapisan yang terdiri dari banyak kristal cair yang diletakkan pada kaca transparan dan memiliki sifat konduktif. Untuk menampilkan suatu gambar, liquid crystal membutuhkan backlight atau reflector sebagai sumber cahaya.

\section{e. Software}

Untuk menjalankan suatu mikrokontroler maka dibutuhkan sebuah software atau program yang akan diinput kedalam mikrokontroler. Program yang diinput berisikan tentang bagaimana pengolahan data input maupun output dari mikrokontroler. Tanpa ada nya program mikrokontroler tidak dapat bekerja, jadi program ini sangatlah berpengaruh dengan kinerja mikrokontroler.

Berikut adalah flowchart jalannya program yang akan diinput dalam mikrokontroler bekerja : 


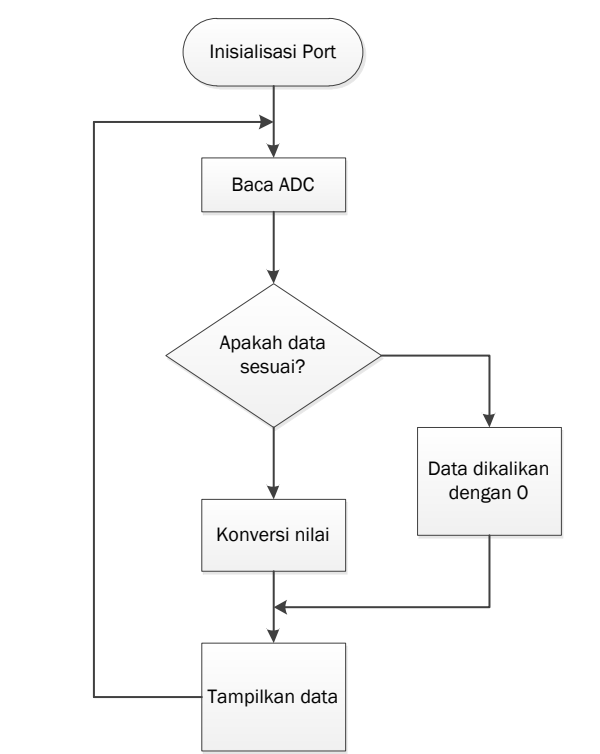

Gambar 9. Flowchart Jalannya Program EMG

Program yang akan diinput ke mikrokontroler merupakan program yang berisi perintah untuk menampilkan data pada LCD dan bagaimana cara mengolah data yang masuk menjadi sesuai dengan yang diinginkan. Berikut ini adalah program yang dibuat untuk penelitian kali ini :

Icd_init(16);

Icd_gotoxy $(0,0)$;

Icd_putsf("PEMBACAAN TEGANGAN OTOT PERUT");

delay_ms(500);

while (1)

\{

dataADC=read_adc $(0$

Icd_gotoxy $(0,0)$;

Icd_putsf("Elektro Unika");

$\operatorname{lcd}$ gotoxy $(3,1)$;

Icd_putsf("O mVOLT");

Temp $=($ dataADC *4.9/10 $)$;

Tamp $=($ dataADC $* 4.9 / 1000)$;

$\operatorname{lcd}$ gotoxy $(0,1)$;

tampil(Temp);

\section{Pengujian dan Analisis}

Penelitian kali ini akan menggunakan ATmega8535 sebagai mikrokontroler dan Muscle Sensor V3 sebagai sensor otot untuk pengambilan data. Muscle Sensor V3 akan dibantu oleh elektroda sebagai antenna yang akan menangkap hasil sinyal tegangan otot yang kemudian akan diolah didalam ATmega8535. Otot yang akan dideteksi sinyal tegangannya akan dipasang oleh elektroda gel pada lapisan kulitnya, kemudian saat otot berkontraksi sensor otot akan mendapat kan data berupa beda potensial listrik yang dihasilkan oleh otot. Data ini akan diolah didalam mikrokontroler sesuai dengan program yang dibuat lalu hasilnya akan ditampilkan ke LCD.

Karena beda potensial yang dihasilkan pada saat otot berkontraksi maka harus dikuatkan terlebih dahulu sebelum data diolah oleh mikrokontroler. Didalam modul Muscle Sensor V3 terdapat komponen AD8226 yang berfungsi sebagai penguat dan mampu menguatkan hingga 1000 kali.

Letak otot yang akan diteliti berada pada bagian otot perut dimana akan diambil 3 titik otot yaitu Rectus abdominis, Internal oblique dan External oblique. Objek penelitian yang diambil juga dikategorikan berdasarkan jumlah IMT (Indeks Massa Tubuh) yang didapat dengan menggunakan rumus perhitungan IMT. Kategori yang diambil yaitu berat badan kurang, normal dan berlebih. Dari hasil pengujian alat akan dapat diketahui termasuk dalam kategori IMT apa mereka dengan perbandingan hasil dari ketiga objek percobaan tersebut.

Berikut ini adalah hasil dari penelitian pembacaan grafik sinyal otot perut dengan menggunakan sensor elektromiografi. 
Seminar Nasional Instrumentasi, Kontrol dan Otomasi (SNIKO) 2018 Bandung, Indonesia, 10-11 Desember 2018

\section{a. Hasil Penelitian IMT 17,71}

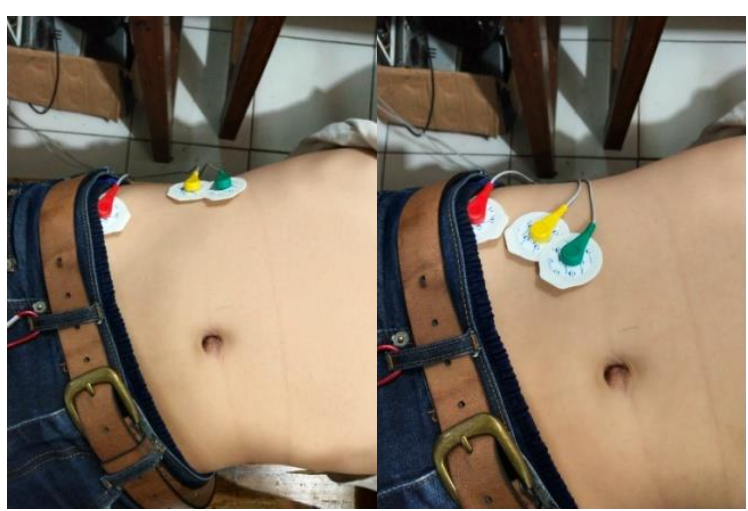

a

b

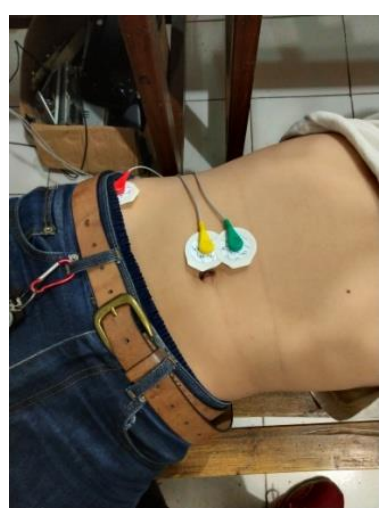

C

Gambar 10. Titik Otot Perut a. Eksternal Oblique; b. Internal Oblique; c. Rectus Abdominis.

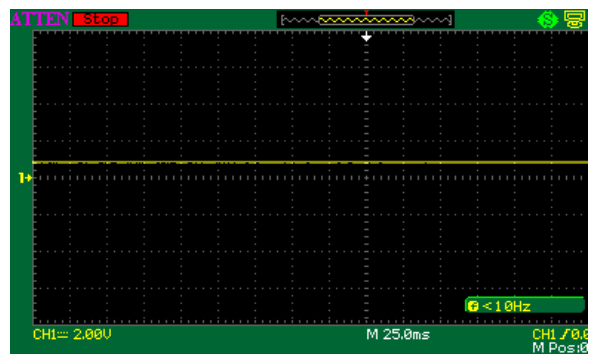

a

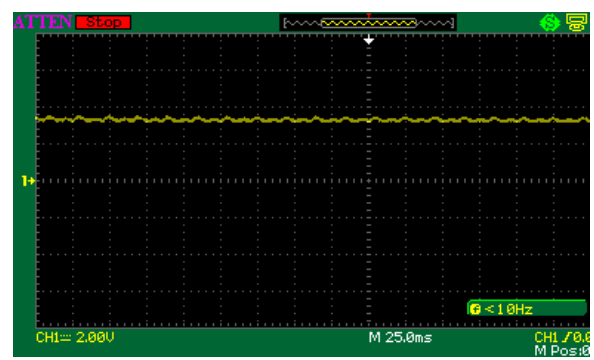

b
Gambar 11. Tampilan Osiloskop Otot Perut Eksternal Oblique a. Kondisi Rileks; b. Kondisi Kontraksi

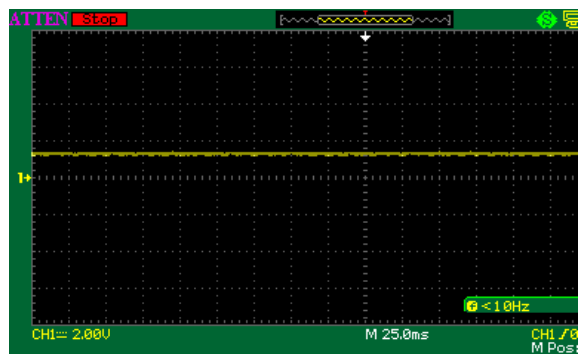

a

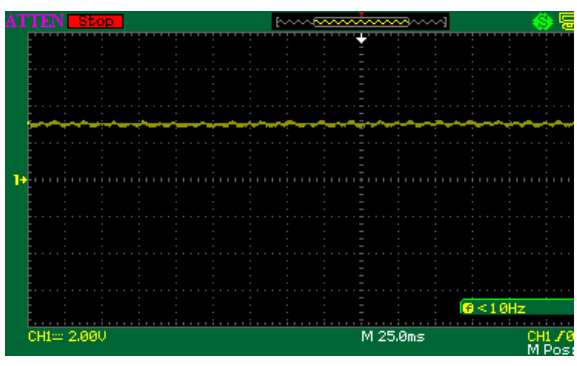

Gambar 12. Tampilan Osiloskop Otot Perut Internal Oblique a. Kondisi Rileks; b. Kondisi Kontraksi
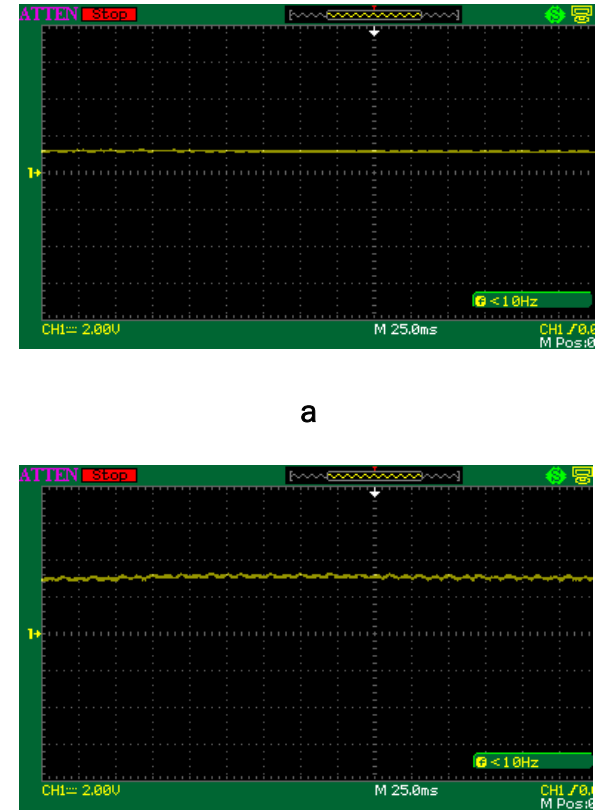

Gambar 13. Tampilan Osiloskop Otot Perut Rectus Abdominis a. Kondisi Rileks; b. Kondisi Kontraksi 
Seminar Nasional Instrumentasi, Kontrol dan Otomasi (SNIKO) 2018 Bandung, Indonesia, 10-11 Desember 2018

\section{b. Hasil Penelitian IMT 19,48}

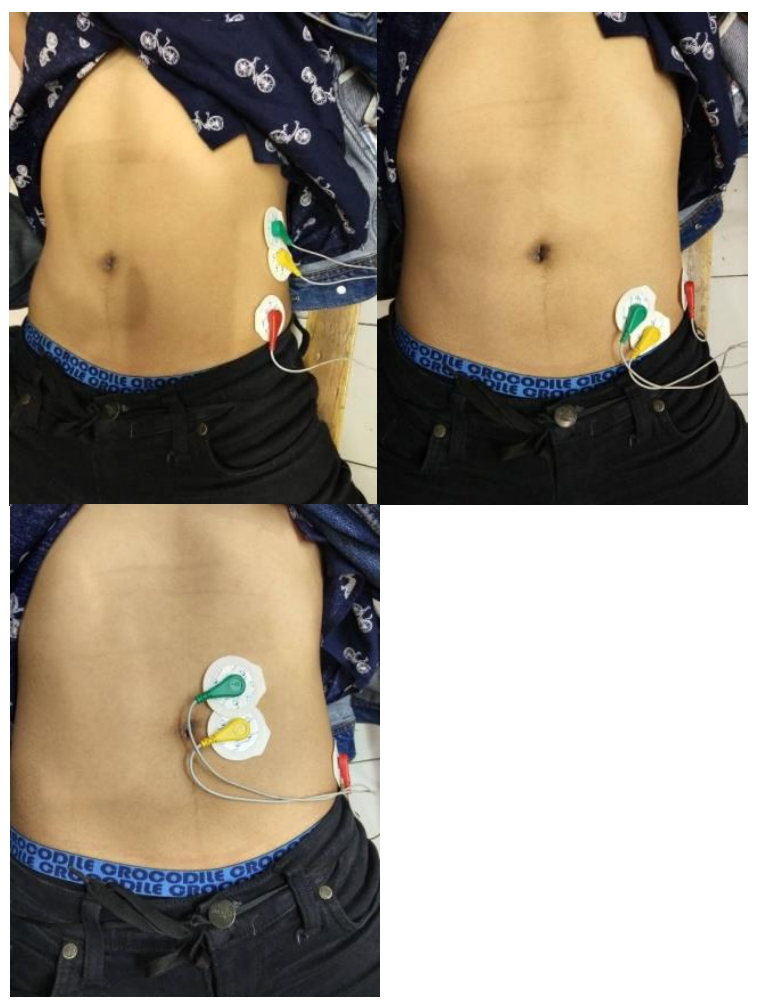

Gambar 14. Titik Otot Perut a. Eksternal Oblique; b. Internal Oblique; c. Rectus Abdominis
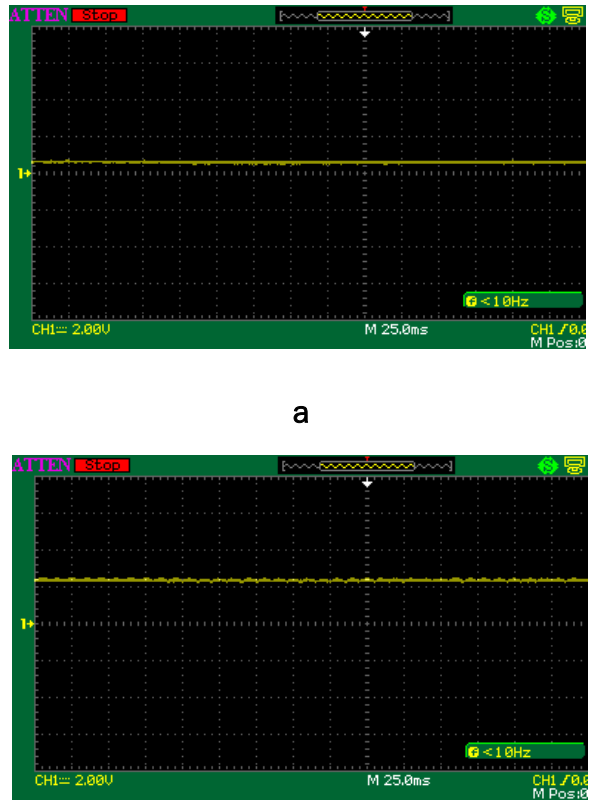

b

Gambar 15. Tampilan Osiloskop Otot Perut Eksternal Oblique a. Kondisi Rileks; b. Kondisi Kontraksi

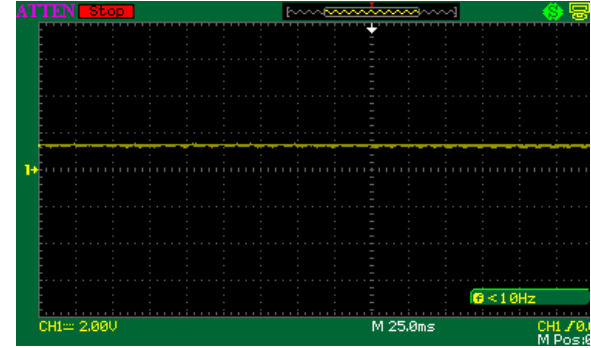

a

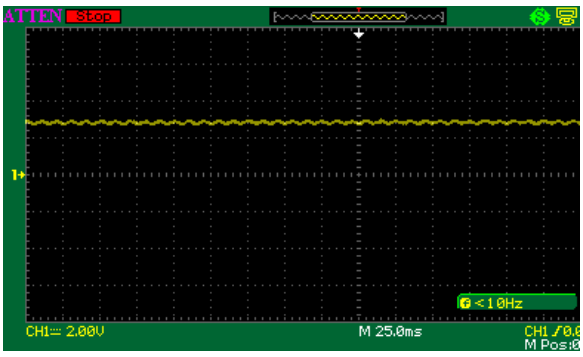

Gambar 16. Tampilan Osiloskop Otot Perut Internal Oblique a. Kondisi Rileks; b. Kondisi Kontraksi
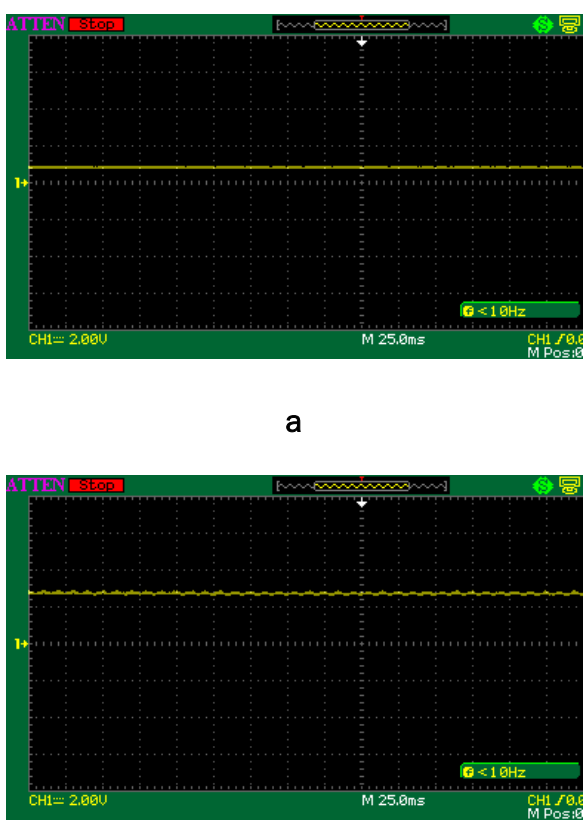

b

Gambar 17. Tampilan Osiloskop Otot Perut Rectus Abdominis a. Kondisi Rileks; b. Kondisi Kontraksi 
Seminar Nasional Instrumentasi, Kontrol dan Otomasi (SNIKO) 2018 Bandung, Indonesia, 10-11 Desember 2018

\section{c. Hasil Penelitian IMT 24,8}

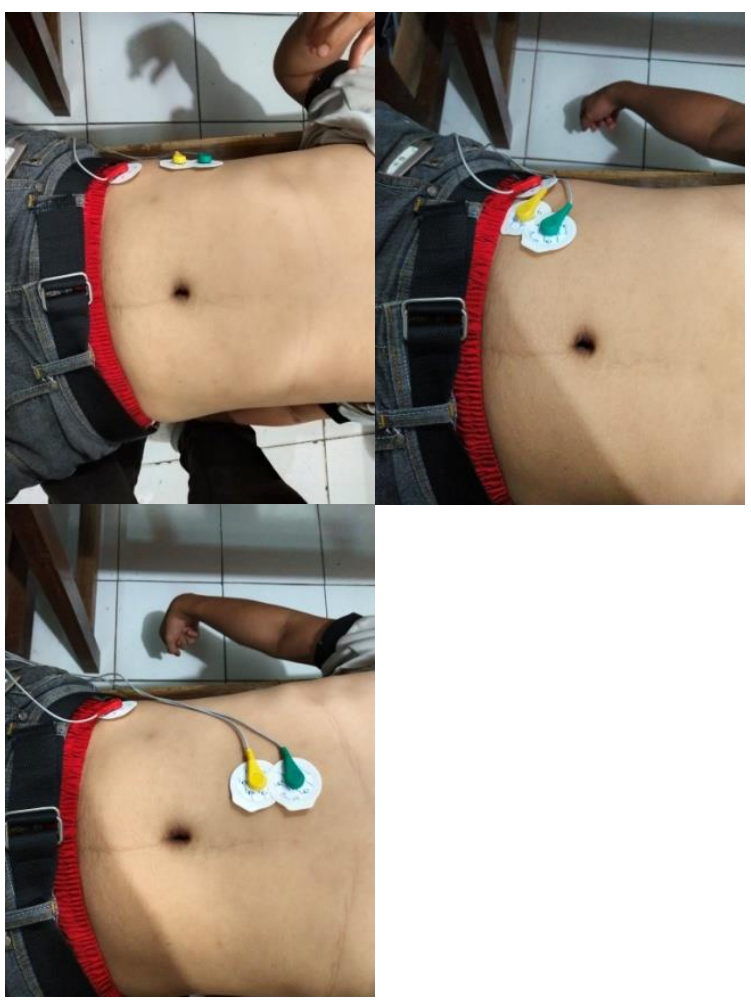

Gambar 18. Titik Otot Perut a. Eksternal Oblique; b. Internal Oblique; c. Rectus Abdominis
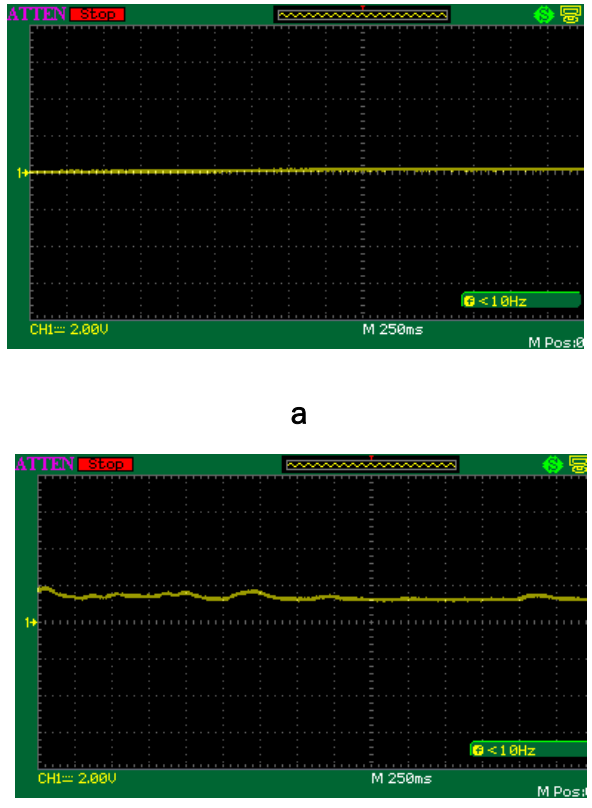

b

Gambar 19. Tampilan Osiloskop Otot Perut Eksternal Oblique a. Kondisi Rileks; b. Kondisi Kontraksi
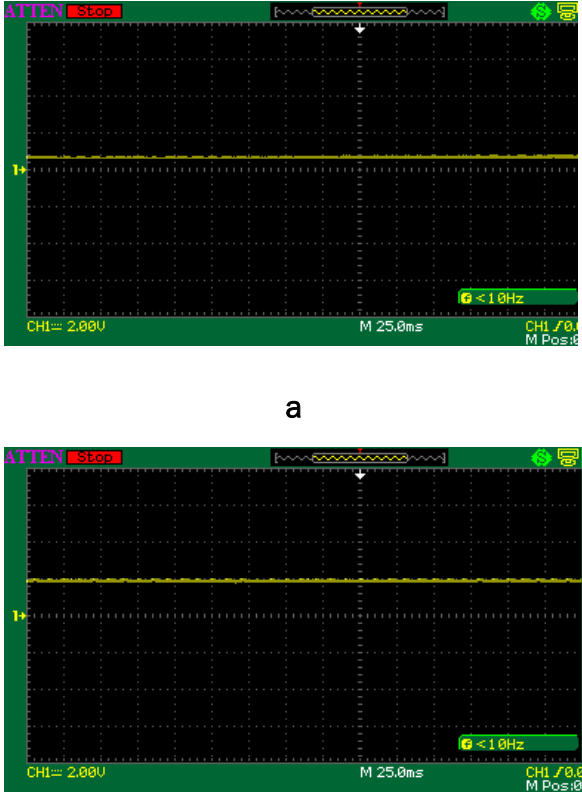

b

Gambar 20. Tampila Osiloskop Otot Perut Internal Oblique a. Kondisi Rileks; b. Kondisi Kontraksi

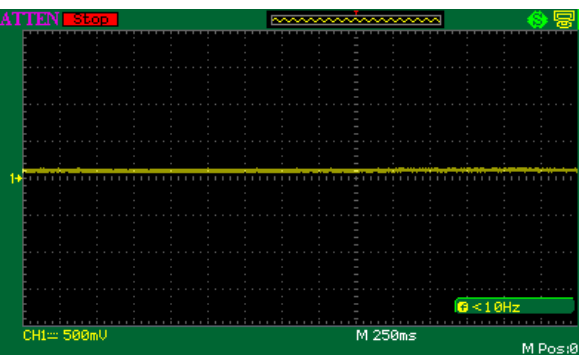

a

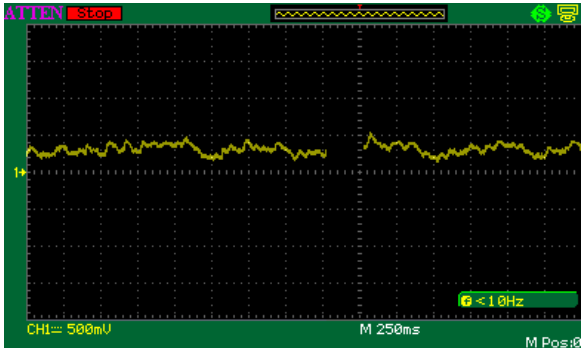

Gambar 21. Tampilan Osiloskop Otot Perut Rectus Abdominis a. Kondisi Rileks; b. Kondisi Kontraksi

Menurut data penelitian yang sudah dilakukan seperti gambar diatas, maka didapat tabel data seperti berikut : 
Tabel 1. Hasil Pengukuran Otot Perut dengan Nilai IMT 17,71

\begin{tabular}{|l|l|l|}
\hline \multicolumn{1}{|c|}{ Jenis Otot } & Rileksasi & \multicolumn{1}{c|}{ Kontraksi } \\
\hline Rectus Abdominis & $\pm 600 \mathrm{mv}$ & $\pm 2500 \mathrm{mv}$ \\
\hline Internal Oblique & $\pm 1300 \mathrm{mv}$ & $\pm 3000 \mathrm{mv}$ \\
\hline Eksternal Oblique & $\pm 780 \mathrm{mv}$ & $\pm 3800 \mathrm{mv}$ \\
\hline
\end{tabular}

Tabel 2. Hasil Pengukuran Otot Perut dengan Nilai IMT 19,48

\begin{tabular}{|l|l|l|}
\hline \multicolumn{1}{|c|}{ Jenis Otot } & Rileksasi & \multicolumn{1}{c|}{ Kontraksi } \\
\hline Rectus Abdominis & $\pm 700 \mathrm{mv}$ & $\pm 2300 \mathrm{mv}$ \\
\hline Internal Oblique & $\pm 1800 \mathrm{mv}$ & $\pm 2900 \mathrm{mv}$ \\
\hline Eksternal Oblique & $\pm 600 \mathrm{mv}$ & $\pm 2400 \mathrm{mv}$ \\
\hline
\end{tabular}

Tabel 3. Hasil Pengukuran Otot Perut dengan Nilai IMT 24,8

\begin{tabular}{|l|l|l|}
\hline \multicolumn{1}{|c|}{ Jenis Otot } & Rileksasi & \multicolumn{1}{c|}{ Kontraksi } \\
\hline Rectus Abdominis & $\pm 100 \mathrm{mv}$ & $\pm 370 \mathrm{mv}$ \\
\hline Internal Oblique & $\pm 620 \mathrm{mv}$ & $\pm 1910 \mathrm{mv}$ \\
\hline Eksternal Oblique & $\pm 160 \mathrm{mv}$ & $\pm 1100 \mathrm{mv}$ \\
\hline
\end{tabular}

\section{Kesimpulan}

Dari data yang diperoleh maka dapat disimpulkan bahwa besar kecilnya data yang diperoleh bisa dipengaruhi oleh banyaknya lemak yang tertimbun pada lapisan kulit dan semakin kecil data maka nilai IMT nya tinggi karena banyaknya lemak yang menghambat perolehan data.

\section{Daftar Pustaka}

[1] State of Alaska. 2011. State of Alaska Measuring Height/Weight and Calculating BMI.

[2] Department of Health and Human Services Centers for Disease Control and Prevention. Body Mass Index: Considerations for Practitioners.

[3] Advancer Technologies. 2013. Three-lead Differential Muscle/Electromyography Sensor for Microcontroller Aplications.

[4] Analog Devices. 2012. Wide Supply Range, Rail-to-Rail Output Instrumentation Amplifier.
[5] Atmel. 2006. Mikrokontroler with 8K Bytes InSystem Programmable Flash.

[6] Florentinus Budi Setiawan, Siswanto. Multi Channel Electromyography (EMG) Signal Acqiusition using Microcontroller with Rectifer. Int. Conf. on Information Tech, Computer, and Electrical Engineering (ICITACEE). 2016.

[7] Ricky Fajar Adiputra, Florentinus Budi Setiawan. Robot Arm Controlled by Muscle Tension Based on Electromyography and PIC18F4550. Int. Conf. on Information Tech, Computer, and Electrical Engineering (ICITACEE). 2016.

[8] Florentinus Budi Setiawan, Siswanto. Electromyography (EMG) Signal Compression using Sinusoidal Segmental Model. Int. Conf. on Information Tech, Computer, and Electrical Engineering (ICITACEE). 2015.

[9] Kevin Eka Pramudita, Florentinus Budi Setiawan, Siswanto. Interface and Display of Electromyography signal Wireless Measurements. International Conference on Information Technology, Computer and Electrical Engineering (ICITACEE). 2014.

[10]Yohanes Oxa Wijaya, Florentinus Budi Setiawan, Siswanto. Desain dan Implementasi Alat Pengukur Ketegangan Otot. Industrial Research Workshop and National Seminar. 2014. 